\title{
"Urban Refugees: Fugitive Slaves and Spaces of Informal Freedom in the American South"
}

\author{
Damian Alan Pargas \\ Leiden University, The Netherlands \\ d.a.pargas@hum.leidenuniv.nl
}

\begin{abstract}
Slave flight in the antebellum South did not always coincide with the political geography of freedom. Indeed, spaces and places within the South attracted the largest number of fugitive slaves, especially southern cities, where runaway slaves attempted to pass for free blacks. Disguising themselves within the slaveholding states rather than risk long-distance flight attempts to formally free territories such as the northern us, Canada, and Mexico, fugitive slaves in southern cities attempted to escape slavery by crafting clandestine lives for themselves in what I am calling "informal" freedom-a freedom that did not exist on paper and had no legal underpinnings, but that existed in practice, in the shadows. This article briefly examines the experiences of fugitive slaves who fled to southern cities in the antebellum period (roughly 1800-1860). It touches upon themes such as the motivations for fleeing to urban areas, the networks that facilitated such flight attempts, and, most importantly, the lot of runaway slaves after arrival in urban areas.
\end{abstract}

\section{Keywords}

slavery - fugitive slaves - Us South - urban slavery - antebellum period

In 1801, a Virginia slave named Ben, "about 26 years of age, 5 feet 9 or 10 inches high, bandy legged, [with] a scar under one of his eyes," decided that he would no longer live in slavery. Escaping his master one night, he bent his course northward and succeeded in getting as far as Baltimore before stopping for a few days to plan his next steps. While there he rashly decided that his best bet 
to ensure a life of permanent freedom would be to not only leave the South, but indeed leave the United States altogether-the northern states were still in the middle of their transition from slavery to freedom at this time, so fleeing farther north may not have seemed as safe as it would in later years. Lurking about the harbor one day, Ben managed to become "secreted in a ship bound to Europe by some free negroes, and was not discovered by the captain till he had been four days at sea, and luckily fell in with a ship bound to Baltimore," where he was immediately arrested upon arrival. His master eventually recovered him and took him back to Virginia. Undaunted, Ben fled again in December of that same year. This time, however, he fled not to Europe nor even to a northern state, but rather concealed himself within the slaveholding South itself, specifically in Alexandria, Virginia, where "his brother Henson [was] one of the Ferry men," and where he sought to live and work undetected among the free black population. ${ }^{1}$

Ben's determination to escape slavery, and especially the way he tried to do so-first making an earnest attempt to leave the South, failing, and ultimately simply hiding out illegally in a southern city - was hardly unique. Indeed, southern newspapers are full of similarly intriguing cases. Almost a quarter of a century later, in the spring of 1825 , for example, Moses Hutcherson, a "likely black fellow about twenty-three years old, five feet four or five inches high, neck somewhat long, and rather a prominent nose for a negro," also determined to escape slavery and live as a free man. Surveying the possibilities to escape bondage from his farm on the Potomac River in southern Maryland, he concluded that the most logical course of action would be to flee to Pennsylvania, where slavery had been abolished. It was an option fraught with peril, of course. Despite the close proximity of the neighboring free state, flight attempts across the Mason-Dixon line were risky at best-Moses would have to traverse dozens of miles of slaveholding borderland undetected by heavily armed patrols and professional slave catchers. In order to disguise the fact that he was a slave he therefore procured forged free papers under the false name of John Henry before starting off, in case he was stopped by anyone. Satisfied that his plan would work, he slipped away from his master's residence on 1 April and made for the North, but his hopes of reaching Pennsylvania were dashed when he was caught just north of Baltimore and thrown into jail. His master recovered him and dragged him back to the southern part of the state. Like Ben, Moses escaped again a month later, this time to the nearby slaveholding city of Washington, where he changed his name again and passed himself off as a free

1 Alexandria Advertiser and Commercial Intelligencer, 18 Dec. 1801 (quote). 
black. Indeed, the free black community of Washington helped him to conceal his true identity and assisted him in finding accommodation and employment. In the months that followed, Moses "served in many of the Taverns and Boarding Houses in [the] District," and remained harbored by "free negroes in [that] place," with whom he had come to have "considerable intercourse."

Unlike thousands of their fellow bondsmen who escaped slavery by crossing state or international borders to parts of the continent where the institution had been abolished, Ben and Moses Hutcherson ultimately succeeded in crafting a life of freedom for themselves by simply disguising their slave identities, living a clandestine life and passing themselves off as free blacks within the slaveholding South. Their stories-and there are innumerable such cases in the history of the antebellum South-complicate our understanding of both the geography of slavery and freedom in North America and beyond, and the opportunities for enslaved people to permanently escape bondage.

Enslaved people ran away with frequency throughout the history of slavery, not only in the American South but in every society in which human bondage flourished. In the New World before the Age of Revolution, such actions were often characterized by various forms of marronage, usually among firstgeneration African slaves. Wilderness maroons-slaves who fled to natural hiding places in the forests or countryside, often in groups-are indeed the freedom seekers that have received the most attention in the academic literature, with Jamaica, Suriname and Brazil standing out specifically for their extensive and well organized maroon societies. But less extensive sites of marronage existed throughout the Americas, including colonial North America (for example in the Great Dismal Swamp of the Virginia-North Carolina border and in the South Carolina lowcountry) and indeed even on the smallest of the Caribbean islands. In heavily deforested Barbados, for example, "divers rebellious and runaway Negroes" were somehow able to avoid detection by "lurking in woods and secret places" such as caves in the mid-seventeenth century. Other maroons crossed borders in times of geopolitical conflict, "marooning" themselves abroad in the hope of securing freedom with the enemies of their masters. In the seventeenth and eighteenth centuries many enslaved people fled to the Spanish Empire, for example - such as the "maritime maroons" in the Caribbean who fled to Puerto Rico or the South Carolina slaves who fled to

2 Daily National Intelligencer (Washington, DC), 4 July 1825 (quotes). For more on the Maryland-Pennsylvania borderland as a destination for fugitive slaves, see for example Richard S. Newman, “Lucky to be born in Pennsylvania': Free Soil, Fugitive Slaves and the Making of Pennsylvania's Anti-Slavery Borderland," Slavery \& Abolition 32, no. 3 (Sept. 2011), $413-30$. 
Spanish Florida-because Spanish authorities were known to refuse extradition of runaway slaves to rival colonies. ${ }^{3}$

A strong argument could be made, however, that the Americas in the Age of Revolution entered a new phase with respect to slave flight, as the hemisphere witnessed an unusual increase in escape attempts due to a number of important changes in the political and social landscape. Simply put, more and more spaces opened up that slaves could run to. The geography of slavery and freedom in the late eighteenth and early nineteenth centuries was radically and irrevocably transformed. For many African Americans, it was an age of emancipation. This period witnessed the legal abolition of the transatlantic slave trade and of slavery itself in various parts of the Americas. Moreover, it witnessed the emergence (or bolstering) of free black communities within slaveholding territories (especially in urban areas) due to a spike in individual manumissions and self-purchase schemes by slaveholders. Yet for countless other African Americans it was an age of what Dale Tomich has called the "second slavery," a period of intensification of slavery in regions such as the American South, Brazil, and Cuba. Indeed, the entrenchment of slavery, even as antislavery scored its first victories, constituted one of the great paradoxes of the Atlantic world. While some parts of the Americas saw their free black populations considerably augmented, others devolved into "freedom's mirror," as Ada Ferrer recently argued. For those still enslaved, the changing landscape of slavery and freedom provided new opportunities to escape and predictably

3 The literature on marronage in the Americas is extensive; what follows is only a very basic sampling. See for example: Richard Price, ed., Maroon Societies: Rebel Slave Communities in the Americas (Baltimore: Johns Hopkins University Press, 1979); Alvin O. Thompson, Flight to Freedom: African Runaways and Maroons in the Americas (Kingston, Jamaica: University of the West Indies Press, 2006); Jerome Handler, "Escaping Slavery in a Caribbean Plantation Society: Marronage in Barbados, 1650s-1830s," New West Indian Guide 71 (Fall 1997), 183-225, 188 (quote). For North America specifically, see for example: Kevin Mulroy, Freedom on the Border: The Seminole Maroons in Florida, the Indian Territory, Coahuila, and Texas (Lubbock: Texas Tech University Press, 1993); Gwendolyn Midlo Hall, Africans in Colonial Louisiana: The Development of Afro-Creole Culture in the Eighteenth Century (Baton Rouge: Louisiana State University Press, 1992); Timothy James Lockley, ed., Maroon Communities in South Carolina: A Documentary Record (Columbia: University of South Carolina Press, 2009). On "maritime maroons," see for example: Jorge Chinea, "A Quest for Freedom: The Immigration of Maritime Maroons into Puerto Rico, 1656-180o," Journal of Caribbean History 31 (Jan. 1997): 51-87; Martin Lienhard, "La mer, espace de liberté? Marrons maritimes aux Caraïbes, 1750-1802," in Bernard Grunberg, ed., Les esclavages en Amérique coloniale: Séminaire d'histoire de l'Amérique coloniale (Paris: Hartmann, 2010), 117-32; Neville A.T. Hall, "Maritime Maroons: Grand Marronage from the Danish West Indies," in Laurent Dubois and Julius Sherrard Scott, eds., Origins of the Black Atlantic (New York: Routledge, 2010), 47-68. 
gave rise to waves of asylum-based migration, as droves of slave refugees-for "refuge" is precisely what they were seeking - crossed into geographic spaces and places that constituted sites of formal freedom (where slavery was abolished according to "free soil" principles, such as Haiti after 1804) or informal freedom (regions within slaveholding territories, especially urban areas, where African Americans attempted to escape slavery by blending in with new free black populations). ${ }^{4}$

In North America the geography of slavery and freedom that emerged in the late eighteenth and early nineteenth centuries was even more complicated, as it included sites of formal, semi-formal, and informal freedom for fugitive slaves. The northern Us, Canada, and Mexico all abolished slavery between 1777 and 1834, either gradually or immediately. Yet only in Mexico and Canada did spaces of full formal freedom from slavery for enslaved freedom seekers

4 For the emergence of "free soil" politics in the revolutionary Atlantic, see for example Ada Ferrer, "Haiti, Free Soil, and Antislavery in the Revolutionary Atlantic," American Historical Review 117, no. 1 (Feb. 2012): 40-66. Ferrer more fully develops her comparison between sites of liberation and entrenchment of slavery in her book Freedom's Mirror: Cuba and Haiti in the Age of Revolution (New York: Cambridge University Press, 2014). For more on "second slavery" in the Atlantic world, see: Dale W. Tomich, "The 'Second Slavery': Bonded Labor and the Transformations of the Nineteenth-Century World Economy," in Francisco O. Ramírez, ed., Rethinking the Nineteenth Century: Contradictions and Movement (New York: Greenwood Press, 1988), 103-17; Ibid., Through the Prism of Slavery: Labor, Capital, and World Economy (Lanham, Md.: Rowman and Littlefield, 2004); Dale W. Tomich and Michael Zeuske, eds., "The Second Slavery: Mass Slavery, World Economy, and Comparative Microhistories, Part I" [special issue], Review: A Journal of the Fernand Braudel Center 31, no. 2 (2008); Anthony E. Kaye, "The Second Slavery: Modernity in the Nineteenth-Century South and the Atlantic World," Journal of Southern History 75, no. 3 (Aug. 2009): 627-50; Javier Lavina and Michael Zeuske, eds., The Second Slavery: Mass Slaveries and Modernity in the Americas and in the Atlantic Basin (Berlin: Lit Verlag, 2014). For abolition in the Atlantic world, see for example: Seymour Drescher, Capitalism and Antislavery: British Mobilization in Comparative Perspective (New York: Oxford University Press, 1987); Ibid., From Slavery to Freedom: Comparative Studies in the Rise and Fall of Atlantic Slavery (New York: Palgrave Macmillan,1999); Christopher Leslie Brown, Moral Capital: Foundations of British Abolitionism (Chapel Hill: University of North Carolina Press, 2006); Robin Blackburn, The American Crucible: Slavery, Emancipation and Human Rights (London: Verso, 2011), 162-69; Seymour Drescher, "Civil Society and Paths to Abolition," Journal of Global Slavery 1, no. 1 (Apr. 2016): forthcoming. For more on the prevalence of manumissions in revolutionary North America and the Americas in general, see Peter Kolchin, American Slavery, 1619-1877 (New York: Hill \& Wang, 2003), 80-85; Ira Berlin, Generations of Captivity: A History of African-American Slaves (Cambridge, Mass.: Harvard University Press, 2003), 119-23, 135-50; Rosemary Brana-Shute and Randy J. Sparks, eds., Paths to Freedom: Manumission in the Atlantic World (Columbia, sc: University of South Carolina Press, 2009). 
emerge on paper (although in practice the meanings of this freedom were contested in a multitude of ways). In the northern Us, where state abolition laws were theoretically curtailed by federal fugitive slave laws, sites of freedom for fugitive slaves remained semi-formal (with state and federal laws conflicting), leaving refugees' legal claims to freedom precarious and often contested in the courts. Even if Moses Hutcherson had reached Pennsylvania, therefore, he still could have been captured and sent back to his master in Maryland. Meanwhile, urban sites of informal freedom for fugitive slaves emerged within the slaveholding South itself after a wave of individual manumissions in the (post-)revolutionary and early federal periods-especially between 1790 and 1810-bolstered free black populations in countless towns and cities across the region, attracting innumerable runaways who attempted to escape their masters by getting lost in the crowd and passing for free. In the Upper South, for example, more than 10 percent of the African-American population was free by 1810, and a significant portion of these free blacks lived in cities such as Baltimore, Washington, and Richmond. In the Lower South the number of free blacks increased less dramatically - from 1.6 percent of the black population in 1790 to 3.9 percent in 1810 - but enough to significantly augment the free black populations of places like Charleston, New Orleans, and countless smaller towns across the southern states. This wave of manumissions at the turn of the nineteenth century "provided the basis for the South's free black population in the antebellum period," as Peter Kolchin has argued, for after 1810 manumission became much more difficult and relatively few slaves were freed. Indeed, in the South as a whole the institution of slavery continued to grow at a feverish pace between the American Revolution and the Civil War, following the expansion of cotton into the southern interior and generating a lucrative domestic slave trade that washed almost a million American-born slaves from the Upper South and eastern seaboard to the Deep South. The more entrenched bondage became in the American South during the era of the second slavery, the more determined some slaves became to flee captivity altogether, enticed by the prospect of freedom in various geographical settings. The border regions of the North, Canada, and Mexico became the destinations of thousands, but urban free black communities within the South attracted the largest number of fugitive slaves. ${ }^{5}$

5 Gary Nash, The Unknown American Revolution: The Unruly Birth of Democracy and the Struggle to Create America (New York: Penguin, 2005), 157-65, 223-31, 320-38, 407-16; Berlin, Generations of Captivity, 119-23, 135-50, 159-244; Kolchin, American Slavery, 80-85, 81 (quote); Sean Condon, "The Slave Owner's Family and Manumission in the Post-Revolutionary Chesapeake Tidewater: Evidence from Anne Arundel County Wills, 1790-1820," in Shute and 
A number of historians have greatly contributed to our understanding of various aspects of slave flight in the antebellum period, with the seminal work by John Hope Franklin and Loren Schweninger, Runaway Slaves: Rebels on the Plantation (1999), standing out in particular for its broad and comprehensive analysis of the subject. Most scholarship on fugitive slaves has tended to focus on escape to sites of formal and semi-formal freedom along the North-south axis, however, especially to the northern us and Canada, and as such misses a broader understanding of the geography of slavery and freedom within North America. Other destinations for fugitive slaves have remained far less thoroughly explored by historians. Although briefly touched upon by Franklin and Schweninger, among others, the "southern underground railroad" that led fugitive slaves to Texas, Mexico, Spanish Florida, and even the Caribbean has only recently begun to receive more in-depth analysis from scholars such as Mekala Audain, Andrew J. Torget, Sarah Cornell, James David Nichols, and Matthew Clavin. And as yet very few scholars indeed have analyzed the experiences of slaves who sought informal forms of freedom by fleeing within the slaveholding states of the South. Those who have, moreover-Franklin and Schweninger, and Stephanie Camp, for example-have tended to underscore the temporary nature of such flight, characterizing runaways who remained in the slave territories as "truants" or "absentees" (temporary runaways or petits marrons) rather than permanent refugees from slavery (long-term migrants or grand marrons). Franklin and Schweninger described the common act of fleeing to the forests that bordered southern plantations as "lying out," for example, and they interpreted runaways who made for urban areas as "temporary sojourners" who experienced a "brief respite from bondage" or at best a "break ... of longer duration" before being caught and sent back to their masters. ${ }^{6}$

Sparks, eds., Paths to Freedom, 339-62; Ellen Eslinger, "Liberation in a Rural Context: The Valley of Virginia, 1800-186o," in ibid., 663-80.

6 John Hope Franklin and Loren Schweninger. Runaway Slaves: Rebels on the Plantation (New York: Oxford University Press, 1999); Philip J. Schwarz, Migrants Against Slavery: Virginians and the Nation (Charlottesville: University of Virginia Press, 2001); Paul Finkelman, ed., Fugitive Slaves (New York: Garland, 1989); Gordon Barker, Fugitive Slaves and the Unfinished American Revolution: Eight Cases, 1848-1856 (Jefferson, NC: McFarland, 2013); Jason Silverman, Unwelcome Guests: Canada West's Response to American Fugitive Slaves, 1800-1865 (Millwood NY: Associated Faculty Press, 1985); Sydney Nathans, To Free a Family: The Journey of Mary Walker (Cambridge, Mass.: Harvard University Press, 2013); Keith Griffer, Front Line of Freedom: African Americans and the Forging of the Underground Railroad (Lexington, Ky: University of Kentucky Press, 2004); Steven Lubet, Fugitive Justice: Runaways, Rescuers, and Slavery and Trial (New York: Cambridge University Press, 2010). For new studies on fugitive slaves in Mexico, see for example: S.E. Cornell, "Citizens of Nowhere: Fugitive Slaves and Free African 
A smattering of more recent works are beginning to challenge the view that fugitive slaves in the South only sought and experienced temporary interludes from slavery, however. Sylvanie Diouf's revisionist study of antebellum America's "borderland maroons" specifically argues that many of these slaves "went to the Southern woods to stay." Alan Taylor's research on runaway slaves in Virginia reveals how fugitives attempted to secure permanent freedom by actively seeking out the assistance of sympathetic British naval officers anchored in the Chesapeake Bay, especially during the War of 1812. And Matthew J. Clavin's work on fugitive slaves in antebellum Pensacola emphasizes the relative ease with which runaways in that seaport town were able to settle and find sustainable employment - although even they often attempted to flee onward to places where slavery had been abolished (especially the British Caribbean). Indeed, many southern cities—St. Louis, Baltimore, New Orleans—ultimately served as "gateways to freedom" for some daring runaways who sought to escape the South altogether, whether because of their proximity to free soil or because of the various transportation possibilities they offered. But runaway slave advertisements and court records consistently indicate that fugitive slaves who concealed themselves in towns and cities across the South often navigated urban areas not merely gateways to freedom in other parts of the hemisphere but as actual sites of freedom in their own right. In other words, they were permanent freedom seekers-at least by intent, and often by outcome-who made illegal yet quite earnest attempts to rebuild their lives in informal freedom rather than bolt for geographic spaces of formal freedom. Understanding why and how they did so is crucial for scholars' reconceptualization of these runaways as freedom seekers rather than mere truants, and for "rerout[ing] the geography of freedom in America" during the age of slavery, as Rachel Adams recently called for. ${ }^{7}$

Americans in Mexico, 1833-1857," Journal of American History 100, nr. 2 (2013): 351-74; Sean Kelley, "Mexico in His Head: Slavery and the Texas-Mexico Border, 1810-186o," Journal of Social History 37, nr 3 (2004): 709-23; James David Nichols, "The Line of Liberty: Runaway Slaves and Fugitive Peons in the Texas-Mexico Borderlands," Western Historical Quarterly 44, no. 4 (Winter 2013): 413-33. Matthew Clavin's recent work views Pensacola as a conduit for fugitive slaves fleeing southward into the Caribbean (especially the British Caribbean). Matthew J. Clavin, Aiming for Pensacola: Fugitive Slaves in the Southern and Atlantic Frontier (Cambridge, Mass.: Harvard University Press, 2015). For a brief overview of the diplomatic consequences of fugitive slaves in North America (only those who crossed international borders), see Jeffrey Kerr-Ritchie, "Fugitive Slaves Across North America," in Leon Fink, ed., Workers Across the Americas: The Transnational Turn in Labor History (Oxford Scholarship Online, 2011).

7 For brief treatment of truancy within the South, especially in urban areas, see for example Stephanie M.H. Camp, Closer to Freedom: Enslaved Women \& Everyday Resistance in the 
This study briefly examines the experiences of fugitive slaves who remained in the antebellum South, with a particular emphasis on the period 1820-1860. During these decades the domestic slave trade (a major trigger for slave flight) reached its pinnacle, internal slave flight increased despite the emergence of clear alternative spaces of (semi-)formal freedom throughout the continent, and southern cities began to enact legislation aimed at stemming the wave of runaways to urban areas. This study touches upon themes such as the motivations that led slaves to flee within the South, and the cooperation between free and enslaved blacks that enabled and facilitated their escape attempts and settlement processes. Most importantly, it advances a new conceptualization of slave refugees in North America by systematically distinguishing between runaways who crossed into geographic spaces and places of formal freedom and those who, like Ben and Moses Hutcherson, escaped slavery by fleeing to sites of informal freedom.

Slaves seeking to permanently escape within the South were often extremely careful and calculated in their plans, and the destinations they chose revealed motivations that went far beyond a simple desire for freedom. When Mathy, "a griff aged about 38 years," and his wife Litty, "black, aged about 35 years," ran away from a Louisiana plantation in the summer of 1845 , for example, they smuggled themselves onto a flatboat and made "their way to South Alabama, where they were lately owned" and where they still had loved ones. Their intention clearly did not include any attainment of formal freedom from slavery-a more logical way to escape bondage from Louisiana in the 1840 s would have been to flee to Mexico or, if they were going to risk concealing themselves on a flatboat anyway, to smuggle themselves up the Mississippi River to Illinois. But for Mathy and Litty, returning to family members from whom they had

Plantation South (Chapel Hill: University of North Carolina Press, 2004), 35-59; and Franklin and Schweninger, Runaway Slaves, 97-103, 124-48. Franklin and Schweninger argued that "few absconders [within the South] remained permanently at large." See John Hope Franklin and Loren Schweninger, "The Quest for Freedom: Runaway Slaves and the Plantation South," in Ira Berlin, Scott Hancock, and G.S. Boritt, eds., Slavery, Resistance, Freedom (New York: Oxford University Press, 2007), 21-39, 25 (quote). For southern runaways as permanent freedom seekers, see Clavin, Aiming for Pensacola; Amani Marshall, "'They Will Endeavor to Pass for Free': Enslaved Runaways' Performances of Freedom in Antebellum South Carolina," Slavery and Abolition 31 (May 2010): 161-80; and Sylvanie Diouf, Slavery's Exiles: The Story of the American Maroons (New York: New York University Press, 2014); Alan Taylor, The Internal Enemy: Slavery and War in Virginia, 1771-1832 (New York: W.W. Norton, 2014). Rachel Adams calls for a broader understanding of the geography of slavery and freedom in North America. See Rachel Adams, Continental Divides: Remapping the Cultures of North America (Chicago: University of Chicago Press, 2009), 61-100. 
been forcibly separated constituted both their prime motivation to flee and the main reason for their choice of destination. Indeed, enslaved people's commitment to family is essential to understanding why so many bondspeople fled their plantations but remained within the borders of the slave South-fugitives within the South often fled with the intention of staying close or returning to loved ones still held in bondage. The threat or reality of forced separation was one of the most important motivations for permanent slave flight within the South, especially by the 1820 s and 1830 s, when the domestic slave trade had turned from a trickle into a torrent. ${ }^{8}$

In the era of the second slavery, when the Atlantic slave trade had been abolished and the domestic slave trade in the southern states flourished, forced separations increasingly wrought havoc on slave families. Eyewitnesses to the domestic slave trade consistently reported that family separations were common. Ethan Allen Andrews, who investigated the trade in 1835 and 1836, found that "family ties are often disregarded in this traffic." Visiting Franklin \& Armfield's slave pen in Virginia in 1836, he discovered that "in almost every case, family ties have been broken in the purchase of these slaves." Another Alexandria slave trader assured Andrews that "he never separates families" upon sale (a lie intended to legitimize his business to the northerner), but admitted "that in purchasing them he is often compelled to do so, for that 'his business is to purchase, and he must take such as are in the market!" When Andrews asked whether the traders often bought wives without their husbands, the reply was: "Yes, very often; and frequently, too, they sell me the mother while they keep her children. I have often known them to take away the infant from its mother's breast and keep it, while they sold her." African Americans living in the supply regions of the interstate trade emphatically corroborated such charges, both during and after slavery. In 1854 James Redpath learned from a northern Virginia slave that the separation of slave families through deportation there was as "common as spring water runs." Another bondsman from North Carolina reported after emancipation that in the region where he lived, the "breaking up of families and parting of children from their parents was common ... and one of the things that caused much bitterness among the slaves." Scholars have

8 Truants and "temporary sojourners" in southern cities, on the other hand, often simply fled to avoid punishment or even for a change of scenery, as Seth Rockman and Franklin and Schweninger have argued. See: Seth Rockman, Scraping By: Wage Labor, Slavery, and Survival in Early Baltimore (Baltimore: Johns Hopkins University Press, 2009), 35-36; Franklin and Schweninger, Runaway Slaves, 126-27 (first quote); The Times Picayune, 10 July 1845 (quote). For more on runaway slaves from the Deep South to Mexico, see Cornell, "Citizens of Nowhere," 351-74; Kelley, "Mexico in His Head," 709-23; Nichols, “The Line of Liberty," 413-33. 
estimated that forced separations probably destroyed one out of every three first marriages among slaves in the Upper South; at least half of all slave families in the region were ruptured through the deportation of either a spouse or child during the antebellum period. Local sales and the westward migration of slaveholders from the eastern seaboard to the southern interior, moreover, severed cross-plantation marriages as well as extended family bonds in countless slave communities. ${ }^{9}$

The rapid expansion of the domestic slave trade from the 1820 on oughly paralleled the completion of the transition from slavery to freedom in the northern states, Canada, and Mexico, and scholars such as Ira Berlin have specifically argued that the dovetailing of these two developments explains why many slaves fled to other parts of the continent in this period. Yet while flight from the South indeed placed thousands of fugitive slaves out of the grasp of southern slave traders, it also permanently separated freedom seekers from their loved ones still held in slavery in the southern states. Despite clear alternative destinations of (semi-)formal freedom outside of the South by the $1820 \mathrm{~s}$, therefore, flight within the South became an important vehicle through which

9 There is a rich literature on the domestic slave trade and the extent to which sales, estate divisions, and long-term hiring forcibly separated slave families in the antebellum period. See for example: Michael Tadman, Speculators and Slaves: Masters, Traders, and Slaves in the Old South (Madison: University of Wisconsin Press, 1989), esp. 133-78; Walter Johnson, Soul by Soul: Life Inside the Antebellum Slave Market (Cambridge, Mass.: Harvard University Press, 1999); Steven Deyle, Carry Me Back: The Domestic Slave Trade in American Life (New York: Oxford University Press, 2005), 246-47; Robert H. Gudmestad, A Troublesome Commerce: The Transformation of the Interstate Slave Trade (Baton Rouge: Louisiana State University Press, 2003); Damian Alan Pargas, Slavery and Forced Migration in the Antebellum South (New York: Cambridge University Press, 2014). Ethan Allen Andrews, Slavery and the Domestic Slave Trade, in a Series of Letters Addressed to the Executive Committee of the American Union for the Relief and Improvement of the Colored Race (1836; Freeport, NY, 1971), 49, 137-39 (first quotes); James Redpath, The Roving Editor: Or, Talks with the Slaves in the Southern States (1859; New York: Negro Universities Press, 1968), 199 (second quote); William Henry Singleton, Recollections of My Slavery Days (n.p., 1922), 2 (third quote). Traders Franklin \& Armfield, to their credit, began to purchase more slaves in family groups after 1834 in an effort to blunt criticism of the slave trade. Other traders, however, spread "fairy tales," claiming to keep families together when confronted with charges of inhumane practices by outsiders. See Gudmestad, Troublesome Commerce, 160-61. Such was the extent of family separation through interstate migration that it even began to affect families' ability to reproduce, especially in the Upper South. In the 1830s, when forced migration reached its peak, the natural growth rate among slaves fell to 24.o percent after having risen in the previous decades. See Calvin Schermerhorn, Money Over Mastery, Family over Freedom: Slavery in the Antebellum Upper South (Baltimore: Johns Hopkins University Press, 2011), 14-15. 
victims of forced migration attempted to either prevent family separations or reunite bonds torn asunder. For slaves living in the supply regions of the slave trade in the Upper South and along the Atlantic seaboard, especially, preventing permanent separations from loved ones underlay innumerable internal escape attempts. Some fugitives who absconded within the South were slaves recently arrived at urban places of market to be disposed of, who fled in order to avoid removal. "Lucy M Downman[']s man [N]at absconded" upon arrival in Richmond in March 1834, for example, and was suspected of having disappeared among the city's large free black population. Nat's owner, from a neighboring county, "had Sent him to Richmond for Sale." Likewise, a "Slave Traders man Henry Jackson" absconded in Richmond in 1834 to avoid being shipped south. Other slaves fled when rumors of potential sale loomed. A fifty dollar reward was offered in North Carolina in 1822 for the apprehension of Jack, a "common mulatto, about 40 years of age," who took with him "his Wife and two Children." Fleeing to prevent a possible separation, the family was suspected of "lurking in Fayetteville, Newbern, or Washington, amongst the free negroes." In 1835 a forty-five-year-old slave woman named Mary, from Charleston District in the South Carolina lowcountry, disappeared amongst the free black population of Charleston when she was confronted with the prospect of moving over a hundred miles to the state capital. A runaway slave advertisement in the Charleston Courier openly claimed that "the cause of her running away was her dislike to be brought to Columbia." And Joe, a 45-year-old Maryland slave from Charles County, "ran off immediately after the appraisement" of his master's estate, "knowing that he was to be sold in a few weeks ..." Joe was suspected of "lurking about the neighborhood of Bryan Town" and passing for free. ${ }^{10}$

For those who were unable to prevent forced removal, fleeing served as a vehicle to reconnect with loved ones lost through forced migration. A significant number of runaway slaves who stayed in the South were themselves forced migrants who had already been sold away from their home communities, and who were fleeing in order to see their families again. Rather than flee to destinations where they could be legally free, they more often ran "home." Slaves who had been sold or removed locally (within the same state or region) were often in the best position to do this, and the evidence from Upper South states

10 Ira Berlin, Generations of Captivity, 161, 241; Daybook of the Richmond, Virginia Police Guard, 12 Mar. 1834, University of Virginia, Alderman Library, Special Collections, Charlottesville, Va. (trans. by Leni Ashmore Sorensen); Ibid., 22 July 1834 (second quote); Raleigh Register and North Carolina Gazette, 26 Apr. 1822 (third quote); Charleston Courier, 3 Sept. 1835 (fourth quote); Daybook of the Richmond, Virginia Police Guard, 9 Oct. 1834 (fifth quote). 
like Virginia and Maryland - where one would expect runaways to make for nearby northern free states-are illuminating. Maria Hamilton, for example, a 24-year-old slave from Alexandria, Virginia, who was sold into the countryside of Fairfax County, was suspected of having run either back to Alexandria, where she had a husband, or to neighboring Washington, where her sister and brother-in-law lived-"she may in all probability have gone there." William Foley, another Virginia slave who ran away from his new master, was suspected of hiding out near "the residence of Mr. Cockerell of Fauquier [County], who owns his mother" and from whom he had been sold away. The runaway Osborn, newly purchased by one William Davison of Winchester, Virginia, "expressed a desire to visit his relations" down the Potomac River in his native Nanjemoy, Maryland, and was suspected to be hiding out there. The latter case is particularly telling because Winchester lies less than fifty miles from the Pennsylvania border but over a hundred miles from Nanjemoy, an interesting example of a runaway slave running literally twice as far to be reunited with family inside the slaveholding South than he would have had to run to attain semi-formal freedom from slavery in a free state. ${ }^{11}$

Remarkably, many fugitives who stayed within the South — both men and women - were victims of the interstate trade and traversed truly vast distances in order to be reunited with families forcibly left behind. As the domestic slave trade scattered black families across the southern states, slave refugees indeed played a prominent role in the "joining of places" (as historian Anthony Kaye dubbed it), creating networks that linked victims of forced migration with their home communities, even across state lines. Southern newspapers from receiving societies are replete with illuminating examples. William, who fled his new plantation near Lexington, South Carolina, in 1830, was presumed to be "mak[ing] his way for North Carolina, as he was purchased ... and brought from there." A Virginia slave woman named Patsey absconded from her Georgia plantation and was suspected to have "endeavored to get back to Virginia," where she still had relations. Interstate migrant Nicholas similarly left his South Carolina plantation in an attempt "to make his way to Maryland," where he was originally from. Sally, a slave from the estate of George Mason in northern Virginia, who was purchased by an Alabama slaveholder, ran away "a few days" after arriving in the Deep South, suspected of making her way back home. "Five Negro Men" from Maryland who had been sold to western Kentucky absconded together in 1838 , suspected of having "endeavor[ed] to get to Cincinnati" and "from thence to Baltimore," amazingly passing through a free

11 Alexandria Gazette, 7 Aug. 1826 (first quote); Phoenix Gazette, 16 Sept. 1826 (second quote); Alexandria Advertiser and Commercial Intelligencer, 9 July 1803 (third quote). 
state in order to get back to their native slave state. In some cases slaves even ran to follow a loved one sold out of state. Dick, a thirty-seven-year-old slave from Kentucky, ran all the way to New Orleans to be with his wife, who was "living in that city" after she had been sold there. Having come from a border state, it would have made more sense for Dick to flee across the Ohio River if he had wanted to free himself from slavery, but as his primary aim was to be reunited with his wife, he fled deep into the heart of the slaveholding South. ${ }^{12}$

Whatever the distances they traversed to be near loved ones, fugitive slaves who remained in the South were in constant danger of being discovered and sent back to their masters, unlike their counterparts who successfully reached geographic spaces of formal freedom such as Canada. Effectively going into hiding or at least concealing their identities to outsiders (especially whites) upon arrival, they depended on others to aid and assist them. Slave families and communities in rural districts provided fugitive slaves with the social networks necessary to sustain themselves for long periods of time without being caught. Refugees who remained in the southern countryside were almost always partly or wholly "harbored" by loved ones, sometimes within slave households but also often in the forests that bordered the plantations or farms where they were originally from. In February $185^{0}$, for example, a $\$ 100$ reward was offered for "the arrest and conviction of the person who has harbored a slave contrary to law named MARGARET," who had been sold from her native Lake Providence to New Orleans and who was "supposed to be at or near Lake Providence," her old community, where she was suspected of being kept hidden by loved ones. Southern newspapers are full of similar examples, but slave testimonies also regularly refer to cases of fugitive slaves in hiding being sustained by loved ones. Kitty, Ben, and Isaac, all three former slaves from the same plantation in Alabama, recalled in a 1910 interview that one bondswoman from their neighborhood "hid with her children in the woods" for a length of "two years," which Ben claimed was a "conservative" estimate. Living her life "in a precarious freedom," the fugitive slave woman reportedly created an underground shelter with a trap door "covered with leaves [so] no one could see it" and depended upon her family and friends, who often left food at the edge of the woods at dusk, to help feed her and her children. Only after the Civil War broke out two years subsequent to her escape were the woman

12 Anthony E. Kaye, Joining Places: Slave Neighborhoods in the Old South (Chapel Hill: University of North Carolina Press, 2007); Charleston Courier, 2 Nov. 1830 (first quote); Charleston Courier, 7 March 1835 (second quote); Charleston Courier, 29 Oct. 1830 (third quote); Huntsville Democrat, 16 June 1838 (fourth quote); The Reporter (Lexington, Kentucky), 2 Dec. 1809 (fifth quote); Lexington Intelligencer, 7 July 1838 (sixth quote). 
and her family eventually able to procure "a freedom not of the swamp, but of the world." Even court documents confirm that such cases were a regular occurrence in the South. Nanny, an "unmanageable" slave from North Carolina, ran away from the employer to which she was hired in 1851, "aided by her ... husband" who was "well acquainted in much of the great Dismal Swamp." Her husband's assistance afforded Nanny "an easy opportunity" to escape to the wilderness indefinitely and avoid arrest. ${ }^{13}$

Such arrangements were desperate and often ad hoc by nature, and they were seldom intended to be permanent, even when they lasted years. Although they certainly did not constitute truancy (these fugitives were not intending to ever return to their masters), they often failed to provide sustainable long-lasting solutions to the refugees' predicament. Most fugitives who were harbored by loved ones in the countryside can more accurately be perceived as runaways still in transit - their final destinations were usually either sites of formal freedom (especially the northern states or Canada) or urban areas in the general vicinity of their home communities. ${ }^{14}$

Urban areas in the South constituted spaces where runaway slaves could realistically attempt to establish a permanent base for themselves in informal freedom - a freedom that did not exist on paper but that de facto allowed them to escape bondage. Most importantly, towns and cities provided refugees with relative anonymity due to the presence of free black communities. In relatively large cities such as Baltimore or New Orleans free blacks were numerous enough to conceal droves of runaway slaves, but runaway slave advertisements from across the South reveal that fugitives often succeeded in eluding detection in small towns as well. In public urban spaces runaways hoped to get lost in the crowd and largely conceal their slave status by pretending to be free blacks, often changing their names-one runaway to New Orleans, for example, was "familiar with the names Hildreth, Brown and Walker"-and changing their appearances to do so. As Amani Marshall has argued, successful procurement of informal freedom in southern cities required runaway slaves

13 Daily Picayune, 21 Feb. 1850 (first quote); John Blassingame, Slave Testimony: Two Centuries of Letters, Speeches, Interviews, and Autobiographies (Baton Rouge: Louisiana State University Press, 1977), 537-38 (second quotes); "William Coppersmith and Elisha S. Nash to the Court of Pleas and Quarter Sessions, Pasquotank County, North Carolina, 1851," in Loren Schweninger, ed., The Southern Debate over Slavery, volume 2: Petitions to Southern County Courts, 175-1867 (Urbana: University of Illinois Press, 2008), 265-66 (third quotes). See also Kaye, Joining Places, 129-35.

14 For a detailed analysis of long-term or even semi-permanent maroon communities in the American South, see Sylvanie A. Diouf, Slavery's Exiles: The Story of the American Maroons (New York: New York University Press, 2014). 
to assume "free identities," which they did by engaging in "intricate performances in which they exploited colour, dress, language, and employment skills to transcend lines of race and class." For slave refugees, passing for free meant looking and acting free. Visibility was everything — erasing all markers of their slave identity was the key to navigating urban spaces undetected. Intriguingly, some light-skinned runaways attempted — sometimes successfully— to pass as white. Granderson, a 23-year-old carpenter from North Carolina who ran away to Washington, was "remarkably white for a slave, and might be readily taken for a white man ... His eyes are blue, his hair very straight ... His purpose is doubtless to pass as a free man." Rezin and Harry, two young brothers from Maryland who were also hiding out in Washington, were "both of so bright a complexion, that they would hardly be taken for mulattoes." But for the vast majority of refugees in southern cities, assuming free identities entailed looking and acting like local free blacks. Indeed, upon arrival in urban areas, runaways' first order of business was often to procure the more fanciful clothing of the free black population to replace the ragged clothes that gave them away as country slaves. Sam, "an artful fellow" from eastern Maryland who had been sold to Kentucky, was presumed to have made his way all the way back to his native town "and will probably exchange his dress" to disguise his slave status. One runaway slave who had been hired out in Livingston, Alabama, was seen wearing "a black cashmere over-coat ... and a silver huntsman's watch," no garb for a slave. ${ }^{15}$

Despite some evidence of class divisions between free blacks and slaves in the antebellum period, in most urban areas these groups formed intricate economic, religious, and familial networks that constituted a "strategy for survival," as Calvin Schermerhorn has argued. Under such circumstances fugitive slaves could usually count on assistance from free black populations, who indeed often helped cloak the true identities of runaway slaves by harboring them in their homes or arranging for safe hiding places. Sometimes these were even free family members. Tarlton, a 24-year-old carpenter from Powhatan County, Virginia, ran away to Richmond in 1834 and was suspected of hiding out at the residence of one Stephen Green, "a free man who lives in Richmond [who] is the Father of Tarlton." Other times the relations between the free black helpers and runaway slaves were less explicit. Julia Johnson, from Staunton, Virginia,

15 Daily Picayune, 3 Mar. $185^{0}$ (first quote); Amani Marshall, “"They Will Endeavor to Pass for Free': Enslaved Runaways' Performances of Freedom in Antebellum South Carolina," Slavery and Abolition 31, no. 2 (June 2010): 161-80, 161 (second quote); Daily National Intelligencer, 4 July 1825 (third and fourth quotes); Frankfort Argus, 28 May 1814 (fifth quote); Mississippi and State Gazette, 5 Sept. 1851 (sixth quote). 
likewise ran away to Richmond, the police noting that "Isaac Adams free [was] Susp[ecte]d of decoying hir [sic] off" and arranging for her hiding place in the city. Molly, who disappeared in the city of Alexandria, Virginia, was believed to be "connected with some evil disposed free negroes, and secreted by them." James Lamar, who fled to New Orleans in 1845, was "harbored near the lower vegetable market, by a free black woman" who sold "victuals and coffee in said market." Such was the extent of the assistance provided by free blacks that southern cities and states repeatedly passed legislation that threatened free black populations with heavy penalties for aiding and abetting runaway slaves. As historian William Link has found, Virginia free blacks ran great risks when they harbored runaway slaves. One free black man in Richmond was whipped in 1853 for allowing a fugitive slave to live in his cellar; a year later another Petersburg resident was brought before the mayor's court for harboring several runaways. In 1856, the General Assembly of Virginia specified that any free person "concerned in the escape of any slave" would receive a prison sentence of five to ten years and a public whipping. The General Assembly of Mississippi passed a similar law in 1839 stating that any free black who helped a slave "to escape from his or her master or owner" would be found guilty of "feloniously stealing [said] slave or slaves."16

Southern towns and cities were also attractive destinations for slave refugees because they provided them with opportunities to perform various occupations and earn money to sustain themselves indefinitely, to the great consternation of slaveholders throughout the South, who often explicitly warned white urban residents against employing their escaped slaves in the mistaken belief that they were free blacks. Skilled slaves-especially men-were often in the best position to do so, as their services were in high demand in urban centers and their occupations often associated with economic activities usually performed by free blacks. Historian Larry Rivers indeed recently argued in his study of slave resistance in antebellum Florida that an exceptionally high proportion of runaways in that state were male skilled slaves, especially carpenters, blacksmiths, and river pilots. Runaway slave ads from other states

16 Calvin Schermerhorn, Money over Mastery, Family over Freedom: Slavery in the Antebellum Upper South (Baltimore: Johns Hopkins University Press, 2011), 24; Daybook of the Richmond, Virginia Police Guard, 14 Mar. 1834 (first quote); Ibid., 28 Sept. 1834 (second quote); Alexandria Advertiser and Commercial Intelligencer, 8 Dec. 1803 (third quote); Daily Picayune, 2 Nov. 1845 (fourth quote); William A. Link, Roots of Secession: Slavery and Politics in Antebellum Virginia (Chapel Hill: University of North Carolina Press, 2005), 104-105 (fifth quote); T.J. Fox Alden and J.A. van Hoesen, Digest of the Laws of Mississippi, Comprising All the Laws of a General Nature, Including the Acts of Session of 1839 (New York: Alexander Gould, 1839), 763 (sixth quote). 
confirm that skilled slaves tended to flee to urban areas within the South with remarkable frequency. Examples from the Charleston newspapers are illuminating. In the summer of 1849 , for example, a $\$ 500$ reward was offered for the apprehension of four bondsmen from a plantation in Rowland's Springs, Georgia, among them an artisan named Hercules. In the prime of his life-he was thirty years old-Hercules "had the peculiar brogue of low country negroes," having been raised in the South Carolina lowcountry and "bought from Charleston recently." The advertisement that announced his absence implied that his master suspected him of having fled to Charleston, where he would have been able to remain in close contact with his home community in the lowcountry. Interestingly, the ad also explicitly specified that Hercules was "a Tinner by trade," presumably because his owner expected him to practice his trade upon arrival in the city. Similarly, Ben Elliott, a twenty-five-year-old runaway originally from Charleston but sold to Augusta in 1833, had been missing for five months before his new master placed an advertisement in the Charleston Courier for his recapture. Ben was presumed to be hiding out in Charleston with his mother, a free woman "named Pheobe Elliott, who sells fruit in the market," and he had already been nearly caught several times passing himself off as a free black and "working about the wharves, and on board vessels, as a Stevedore or an Assistant." Peter Youngblood fled his new Charleston residence for the town of Beaufort, "as he has a wife on Mrs. Hamilton's Plantation, in that neighborhood." An experienced boatman and a fisherman, he was suspected of being "employed in fishing in the neighborhood of that city."17

Southern towns and cities also provided female fugitive slaves with economic opportunities to sustain themselves indefinitely; runaway slave women indeed often succeeded in finding domestic employment in white households, their employers assuming that they were free blacks. "Fifty Dollars Reward" was offered "for the apprehension of TENAH, a female servant, who ran away from Barnwell Court House [South Carolina] on the $12^{\text {th }}$ September" in 1830. Like many of her counterparts, Tenah had been separated from her loved ones when she was sold from a plantation near Charleston to Barnwell. The runaway

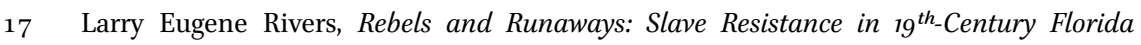
(Urbana: University of Illinois Press, 2012), 66-67. Greenville Mountaineer, 17 Aug. 1849 (first quote); Charleston Courier, 7 March 1835 (second quote); Ibid., 28 Sept. 1830 (third quote). A study of runaway slave profiles in North Carolina comes to the same conclusion, with blacksmiths, carpenters, coopers, and shoemakers heavily overrepresented in runaways from that state. See Freddie L. Parker, "Runaway Slaves in North Carolina, 1775 to 1835 " (PhD dissertation, University of North Carolina, Chapel Hill, NC, 1987), 197-99. 
slave ad that announced her flight stated that she was "brought to this city in June last, at a sale of the estate of Vancy's Negroes, and it is believed that she is harbored in Charleston by a free person," her husband being "a free man by the name of William Lewy, who lives in Goose Creek, and has been seen in her company at the person's house in which she is harbored." Tenah was suspected of illegally passing herself off as a free black woman in order to gain employment, as her master "understood that she has been (perhaps unknowingly) employed by a white person as a washerwoman." Similarly, a slave woman named Milly was "Supposed to be in Richmond" where she had been hired in the household of one Fleming Griffiths; she fled and was suspected of hiring her services to another employer as a free woman. ${ }^{18}$

A significant portion of the enslaved population in any southern town or city consisted of hirelings, and hired slaves in turn made up a significant number of slave refugees in urban areas. Self-hire arrangements, whereby a slave (usually a male slave) was sent by his master to the city to hire himself, were common enough that some runaway slaves in the cities even attempted to disguise their identities by passing for hired slaves rather than free blacks. John Lewis, a Kentucky slave, ran away to Lexington with the intention of pretending "he has hired his own time." Most tried to pass themselves off as free, however. Indeed, hired slaves' absence from their masters, relative lack of supervision and freedom of movement, as well as their first-hand experience with urban labor markets, placed them in an advantageous position to navigate southern cities disguised as free blacks. They knew the ropes, worked with and rubbed shoulders with free black populations, and were keen to trade in their "quasifreedom" (as Jonathan Martin dubbed it) for freedom, albeit informal freedom. For these runaways, the determination to live in freedom and the conviction that they deserved the fruits of their own labor were often more important motivations to flee bondage than family reunification. Henry, a refugee in New Orleans who had been "hired in this city as a drayman," absconded and found work for himself "in the shipping and about the levee," keeping his earnings for himself. Urban hirelings also had the networks necessary to pull off a successful escape attempt. William Lee, a "smart, sensible, and very plausible fellow" as well as a "good wagoner" who had been hired in Fauquier Court House, Virginia, was suspected of hiring himself out around town as a free man. Lee had "extensive acquaintances" in the town, which facilitated his flight. Another Virginia slave who went missing in 1825 "had been hired in Alexandria for some 
months past," her owner lamenting that "she is well known" there and would no doubt be aided in her flight. ${ }^{19}$

As stated above, the ability of fugitive slaves to abscond to and successfully earn a living in urban areas by passing themselves off as free blacks produced great consternation among slaveholders, who demanded that municipalities tighten police supervision of African Americans' economic activities in public spaces. City councils throughout the South explicitly complied with such demands, at least on paper. The city of Little Rock, for example, passed "an ordinance, concerning Slaves, and free Negroes and Mulattos" in January 1836, that declared among other things that "No person shall buy or receive from any slave any commodity whatever in this City, unless the said slave shall produce a written permit from his or her master, mistress or overseer." Since free blacks could reasonably be suspected to be slaves until proven otherwise, this ordinance was implicitly intended to force white customers to ask black sellers for their papers before purchasing any wares from them, presumably in order to uncover fugitive slaves who were living illegally in the city. Similar ordinances were passed throughout the South, but in practice they were often poorly enforced, both by the authorities and by white customers. ${ }^{20}$

Southern municipalities largely failed in their attempts to distinguish between free blacks and runaway slaves in public spaces, despite strict legislation aimed at enhancing the visibility of both, such as requiring slaves to carry passes and free blacks to carry free certificates at all times. Fugitive slaves' existence in the cities was precarious owing to the fact that they lacked formal papers to prove that they either had permission to reside in the city or that they were free. As illegals and non-citizens, the very public spaces that often provided them with anonymity could also produce dangerous encounters with whites that might reveal their true identities. Documentation-false documentation - was a great advantage for those who could procure it. Slaves

19 Jonathan Martin, Divided Mastery: Slave Hiring in the American South (Cambridge, Mass.: Harvard University Press, 2004), 161-87; Franklin and Schweninger, Runaway Slaves, 134-45; The Reporter (Lexington, Kentucky), 1 Apr. 1812 (first quote); Daily Picayune, 19 Feb. 1850 (second quote); Daily National Intelligencer, 8 Jan. 1820 (third quote); Daily National Intelligencer, 4 July 1825 (fourth quote); Daily National Intelligencer, 20 Feb. 1826 (fifth quote).

20 Arkansas Gazette, 12 Jan. 1836 (quote); Kimball, American City, Southern Place, 124-58; Seth Rockman, Scraping By: Wage Labor, Slavery, and Survival in Early Baltimore (Baltimore: Johns Hopkins University Press, 2009), 52-53; Campbell, Slavery on Trial, 146-85; Thomas C. Buchanan, "Rascals on the Antebellum Mississippi: African American Steamboat Workers and the St. Louis Hanging of 1841," Journal of Social History 34 (Summer 2001): $797-817$. 
who could read and write were in a position to forge their own passes or free papers, and many did. Frederick, a Georgia slave who was suspected of having run to Augusta in 1825, was presumed to be carrying "a forged pass with him, as he can read and write." Ben, a Virginia slave who ran away with his three daughters to Washington, could "write a pretty good hand, and no doubt has copied the papers of some free man," and his master had "reason to believe he stole the Stafford County seal and attached the impression of it to his papers." Most slaves were illiterate, however, and therefore depended on free blacks to provide them with the false documentation necessary to evade detection. Perhaps unsurprisingly, a black market in forged passes and facsimiles of free papers for runaway slaves - the antebellum equivalent of a fake passport for today's undocumented immigrants - flourished in urban areas, despite strict legislation against it. In Mississippi the General Assembly explicitly threatened felony prosecution of "any free negro or mulatto who shall deliver or transfer to any slave the copy of the register of his or her freedom ... with the intent to enable such slave to escape from his or her master." Every other southern state had similar legislation on the books, and by the eve of the Civil War even the sparsely settled southwestern territory of New Mexico warned that "any person furnishing slaves free papers is liable to an imprisonment of not less than six months nor more than five years, and a fine of not less than $\$ 100$ nor more than \$100o." Yet runaway slave ads reveal that forged papers were common anyway. Nancy, a "bright mulatto, aged about 25 years" and originally from the Natchez area of Mississippi, absconded from her new master in Plaquemines Parish, Louisiana, but had "lately been heard of in the neighborhood of Natchez with a forged pass." Kitty, a Virginia slave suspected of having run to Washington, was advertised as "uncommonly artful, and no doubt will have free papers." Amanda, from Monroe County, Georgia, fled to Augusta with "a pass given her" so that she could "attempt to pass as a free person." David, "by profession a Methodist preacher" from Kentucky who ran to Lexington with his friend Charles, was understood to have "a forged pass." And Will, a Virginia runaway, "probably has a pass or counterfeit papers of freedom." ${ }^{21}$

21 Augusta Chronicle, 8 Oct. 1825 (first quote); Daily National Intelligencer (Washington, DC), 4 July 1825 (second quote); Alden and Hoesen, Digest of the Laws of Mississippi, 763 (third quote); Bangor (ME) Whig and Courier, 17 Mar. 1859 (fourth quote); Times Picayune, 30 July 1845 (fifth quote); Alexandria Gazette, 1 Jan. 1822 (sixth quote); Augusta Chronicle, 13 July 1827 (seventh quote); The Reporter (Lexington, Kentucky), 18 Oct. 1815 (eighth quote); Daily National Intelligencer, 8 Jan. 1820 (ninth quote). For more on cooperation between urban free blacks and slaves within the realm of resistance, see: Kimball, American City, Southern Place, 124-58; Seth Rockman, Scraping By: Wage Labor, Slavery, and Survival in Early Baltimore (Baltimore: Johns Hopkins University Press, 2009), 52-53; Campbell, 
Such passes became increasingly necessary after the Nat Turner insurrection in 1831, when urban southerners became more vigilant in requiring free blacks to carry papers, and slaves to carry passes or badges, to prove that they resided in the city legally. Because assuming a false identity and a false legal status was so crucial to fugitives' lives in urban areas, those who failed to procure documents ran high risks of recapture. One slave owner from Columbia, South Carolina, advertised for his runaway slave named Mary, who fled back to her native Charleston in 1859, describing her as having "neither ticket nor badge, as required by the City Ordinance." When recapture seemed imminent for those who were discovered without passes or papers, they often fled again, this time to geographic spaces of formal freedom, a risky venture that was wrought with hazards. One slave couple named George and Jane, from Henrico County, Virginia, was recaptured in an escape attempt that illustrates the volatile existence of refugees in the cities. Having each fled the employers to which they were respectively hired in 1833, the two fugitives came together and made their way to neighboring Richmond. Upon arrival "George passed himself off as a freeman \& hired himself as a cook on bord [sic] the schooner John Bendil," docked in the James River. When the captain of the ship eventually asked for George's free papers before departure, he "found that he was in fact a slave \& not a freeman having a right to hire himself." George fled in panic, concealing himself on board a schooner bound for New York, where he was later discovered and arrested. Jane was also arrested, "making similar efforts to leave the state" and join her husband in the North. Many fugitives who eventually reached geographic spaces of formal freedom had indeed originally attempted to create lives for themselves in informal freedom in towns and cities across the South, but were forced to take flight again when they were detected. ${ }^{22}$

In conclusion, a thorough understanding of the geography of slavery and freedom on the North American continent in the antebellum period must include closer analysis of fugitive slaves who sought freedom by remaining within the slaveholding states. The actions of these runaways went far beyond mere truancy, unlike what is often suggested in the literature. Fugitives to urban

Slavery on Trial, 146-85; Thomas C. Buchanan, "Rascals on the Antebellum Mississippi: African American Steamboat Workers and the St. Louis Hanging of 1841," Journal of Social History 34 (Summer 2001): 797-817. William Link has found that the policing of documentation for free blacks and slaves in urban environments in Virginia was at best "sloppily maintained." See Link, Roots of Secession, 106.

22 Charleston Courier, 1 Jan. 1859 (first quote); "Thomas Cowles to the County Court, Henrico County, Virginia, 1833," in Schweninger, ed., Southern Debate over Slavery, 163 (second quotes). 
areas indeed clearly attempted to live their lives there indefinitely, and even maroons did not intend to return to their masters but were more often "in transit" to other sites of formal or informal freedom. Distinguishing between sites of formal freedom (where fugitives could be legally free) and informal freedom (where fugitives attempted to live free illegally) as permanent destinations for runaway slaves is also crucial in understanding how slaves understood freedom (i.e., not always in political terms) and what their prime motivations for fleeing bondage were. Indeed, the decision to seek any type of freedom appears to have been strongly influenced by slaves' desire to restore or protect family ties that were threatened with forced separation. Unlike their counterparts to the North, however, those who sought informal freedom clearly placed maintaining contact with loved ones still in bondage-even if it meant living illegally within the slave states - above the procurement of political or civil rights, which supports recent scholarship by historians such as Calvin Schermerhorn, who has argued that slaves in the antebellum South almost always preferred "family over freedom" - at least formal freedom. ${ }^{23}$

23 Schermerhorn, Money over Mastery, Family over Freedom. 